OPEN ACCESS

UNIVERSITY OF THE

WEST of SCOTLAND

UWS Academic Portal

\title{
The political is personal
}

McCrory, Marjorie; Thomson, Theresa

Published in:

Journal of the National Institute for Career Education and Counselling

DOI:

10.20856/jnicec.4202

Published: 01/04/2019

Document Version

Peer reviewed version

Link to publication on the UWS Academic Portal

Citation for published version (APA):

McCrory, M., \& Thomson, T. (2019). The political is personal: Brexit and the career aspirations of UK undergraduates. Journal of the National Institute for Career Education and Counselling, 42(1), 3-8.

https://doi.org/10.20856/jnicec.4202

\section{General rights}

Copyright and moral rights for the publications made accessible in the UWS Academic Portal are retained by the authors and/or other copyright owners and it is a condition of accessing publications that users recognise and abide by the legal requirements associated with these rights.

Take down policy

If you believe that this document breaches copyright please contact pure@uws.ac.uk providing details, and we will remove access to the work immediately and investigate your claim. 


\title{
The political is personal: Brexit and the career aspirations of UK undergraduates
}

\section{Dr Marjorie McCrory and Theresa Thomson}

\begin{abstract}
Findings from a small-scale qualitative research project exploring the impact of Brexit on the career aspirations of final year students at a UK university reveal the centrality of values and emotion in career decision-making. Although not conclusive or generalisable, these findings nevertheless demonstrate the impact of the wider context of the world we live in, and specifically, of political events, on perceptions of career and potential career choice. This presents a challenge to career development theorists and practitioners alike to adequately address and respond to the impact of the political in relation to career decision-making.
\end{abstract}

\section{Why study the impact of Brexit on graduate career choice?}

In an era of global economic austerity and the rise of right-wing populism across Europe, the UK faces the considerable challenge of securing longer-term outcomes that are both economically and politically favourable. Lingering uncertainty around this process will almost certainly impact on both the perceptions and the material circumstances of UK graduates, as they contemplate their career options and embark upon their post-graduation careers. More generally, and of some significance in relation to our understanding of career decision-making, the 2016 Brexit referendum presents us with an opportunity to consider the effects of political events on individuals' perceptions of career, and challenges theorists and practitioners alike to consider whether adequate understandings of, and responses to, such events are sufficiently foregrounded in theory and practice. Here, the authors seek to present the findings of this small-scale study as a means to stimulate further thinking and discussion around these broader issues.

There is no clear consensus on the likely impact of Brexit on graduate employment in the UK (Hobson, 2018; BBC News 2018). However, large-scale quantitative surveys of UK undergraduates, from predominantly Russell Group universities, suggest that up to three quarters of graduates believe that it will be harder to find 
graduate-level employment as a result of the decision to leave the EU (Higher Fliers Research, 2017) and research by Trendence UK (as cited in Recruitment International, 2017), suggests that $77 \%$ of domestic students believe that there will be fewer opportunities to work or study overseas.

To explore the impact of this political event on graduates' career thinking, 15 indepth individual interviews were conducted with final year domestic-domiciled undergraduates at the University of the West of England in Bristol, with participants drawn from a cross-section of degree programmes. (Participants were all UK nationals, age 21 to 26 years old, seven male and eight female.) The interviews were conducted from July until December in 2017, i.e. 12-18 months after the 2016 Brexit referendum result. It is important to note that the timing of the study was sufficiently close to the referendum result to capture participants' reactions, feelings and opinions relating to it. However, enough time had passed for participants to have digested the potential impact of the referendum result on their lives, particularly as they entered their final year of undergraduate study. Therefore, one may posit with reasonable confidence that the thoughts and opinions expressed during the research interviews were not merely 'knee jerk' emotional reactions in the immediate aftermath of the referendum, but were more thoughtful reflections developed in the post-referendum period.

In brief, a thematic analysis of the interviews identified two broad, yet interrelated themes: a stronger emphasis being placed by participants on personal values and commitments when considering career choice, and anxiety about the future in an uncertain economy and potentially divided society. These findings can be seen to be directly attributable to the Brexit campaign and the referendum result. Significantly, we wish to argue that participants' expressions of emotion, and of the importance of personal values and commitments, signal career thinking that requires understandings and responses that adequately reflect the nature of the interrelatedness of individual and social factors; that is, understandings and responses that grasp the generative power of socio-political circumstances and events in relation to career thinking, without diluting the creative and meaningful agency of individuals to respond to these events. 


\section{Brexit: values and commitments drive career thinking and action}

Amongst participants, Brexit appeared to kindle a sense of both social purpose and personal responsibility in response to perceptions that the referendum had created, or exposed, social division;

'It's definitely made me more motivated to try and create a better society.' (Participant 9),

'Maybe before I was just, I want some job. But now it's, "What can I do? What can I contribute?" So it's probably made me a lot more passionate, but also more serious about it.' (Participant 7)

Participant 1 echoed these sentiments, suggesting that, though their career choice may not have changed, it meant something different now, and that would lead to a particular kind of engagement;

'I want to be a teacher, this kind of teacher, because of Brexit, I'd try and work where maybe there are signs of this kind of division. I'd seek out the problem. I'm not sure if I'd succeed, but I'd at least try.'

One participant linked their career thinking clearly to broader identity issues, suggesting that their career ideas linked directly to enacting a vision of how the future should be;

'I don't want to be seen as that English person who has these beliefs and values, working in a place where this is all we are, this is England, this is how we'll stay. l'd want to work with people and try and open up the social boundaries.' (Participant 10)

Participants also linked their career thinking to broadening and deepening understandings of the place, and nature of work in their lives and in relation to society; 
'It's made me realise that you can't just go and do a job, 9-5, earn your money, go home, because that's not how society changes for the better.' (Participant 4)

\section{Brexit stress: uncertainty and anxiety reveal political career thinking}

All 15 participants in this study construed the Brexit campaign and referendum result as having been a negative experience, characterised as revealing a divided country, which they believed would be perceived as unwelcoming and isolated;

'I thought we were doing so well, and then people mass supported something I thought we'd overcome. With Trump, and with Brexit... it's just lowered the bar.' (Participant 4)

'I thought we were better. I thought we were a progressive country.' (Participant 15)

More specifically, participants identified issues relating to intolerance of diversity and a form of isolationism as alienating;

'Not that I would argue that everyone's a racist, or that everyone's intolerant, but it definitely does feel like a sort of cultural isolationism going on in the UK. There's some sort of regression going on, an intolerance towards migrants. And I think maybe Brexit didn't create that, but it definitely revealed it. Or maybe legitimised it.' (Participant 9)

For some participants, these issues related quite directly to career thinking;

'The impact it will have on me specifically is that I won't look for work in the UK and I won't continue my studies in the UK.' (Participant 6)

'I don't want to live in a place where those values aren't existing or they're going backwards. So that's definitely pushed me away. So I don't think I'll live in England. I would live in England if we stayed in the EU.' (Participant 9)

Anger, frustration and a sense of confusion were palpable in the interviews; 
'Brexit, and then the Trump vote, and then the last General Election, it just seems to be cascading massive amounts of civil unrest, where it's "Do I really want to be in a state where I can see things potentially collapsing?" It begs the question, "Is this a state that I want to reside in? Or pay taxes into anymore, when it can't do its main purpose of keeping civilisation unrest as low as possible?" It's certainly a consequence of the political climate we're in.' (Participant 7)

As well as anger, a sense of sadness was expressed by participants and this was expressed quite directly in relation to the individual's relationship with society and their place in it;

'It makes me upset because I feel excluded a little bit from society.' (Participant 6) 'It's just a world I don't want to have to live in because it seems to be going back, you know, five steps.' (Participant 3)

At a time where there are increasing numbers of students in higher education reporting mental health issues (Universities UK, 2018), these sentiments are clearly concerning, and participants expressed specific anxieties when talking about the future;

'It's all like is everything going to go wrong now? That sort of sensation.' (Participant 4).

'This world that I'm going to be an adult in, that l'm going to be working in, that I'm going to be bringing my own children into, is it going to be a very secure one? I was nervous, I must say.' (Participant 11)

Anxiety was also evident when participants reflected more specifically on their likely future job prospects;

'I think it's made people a bit more stressed out. There's more confusion and people are getting panicked. I think it's because of the uncertainty. People at university keep going on about it. Because it's brought up in the news so often, it's always at the forefront of the discussion of things.' (Participant 14) 
Although it was acknowledged that Brexit 'might make finding a job harder' (Participant 2), the concern expressed by a few participants was not so much about lack of job opportunities in the UK, but more about their perception of restricted opportunities to live and work in Europe;

'I never really thought about it, but then as soon as the door was closed off, it was almost noticeable that I had that opportunity, I had some bridge into Europe. Now a lot of those doors have been closed off.' (Participant 1)

Uncertainty about future opportunities caused particular anxiety;

'You don't know what they're doing, so you can't really be worried about the implications of what they are doing. They don't seem to know. That's more unnerving than worrying about something concrete, isn't it?' (Participant 1)

'I feel that if I worry about it now, I'll be completely stressed out.' (Participant 14)

Some recognised that adaptability and a positive mind-set would be needed;

'It's about being adaptable and ... resilient to the change.' (Participant 8)

This sentiment was echoed by participant 10;

'Things change, people change. The world is ever changing.'

Surprisingly perhaps, given the overwhelmingly negative view of the referendum result, there was some cautious optimism amongst participants. This too reflected participants' concerns with values and commitments;

'Jobs are out there, and they are jobs where an impact can be made.' (Participant 8),

'The world is still going to need teachers and childcare workers. That's not going to go away because we've left the EU.' (Participant 11)

Towards the end of the interviews, a few participants sounded more hopeful about the personal impact of Brexit; 
'Martin Lewis, the money-saving expert guy, he predicts that in the long term, we might be better off.' (Participant 13)

'Maybe it's time for a change?' (Participant 5)

It is perhaps worth noting, in light of these more hopeful statements, that the interviewer did consider the potentially therapeutic aspects of the research interview in the context of what were emotionally-charged, and sometimes quite upsetting, discussions. Although not a focus of this paper, this possibility suggests some potentially significant connections between research interviewing and therapeutic interventions that are directly relevant not only to research practice, but also to career guidance and development practice (Amundson, 2003; McCrory and O'Donnell, 2016).

\section{The political is personal}

The politics of career guidance is generally discussed in relation to a number of key agendas, including the impact of policy regimes on service delivery and practice. In addition, the salience of class and opportunity structures (including welfare regimes) in relation to career perception and career choice is well understood (Hooley and Barham, 2016; Roberts, 2009) and issues relating to the geographical aspects of labour markets have complexified our understanding of structural 'determinants' (Alexander, 2018). More recently, issues of social justice have been widely discussed in relation to policy agendas and service delivery as well as in relation to the mechanics of service delivery and practice (Hooley, 2015; Thomsen, 2017). Arguably, discussions around the relationship between career guidance practice and conceptualisations of social justice come closest to addressing the issues that we seek to highlight here; specifically, the need to address the ways in which individual decision-making is, in some meaningful sense, always inherently social and, by extension, political. Such a focus would suggest a need to work with individuals without assuming their 'individuation' (Marx, 1973). 
Expressions of values and commitments shed some further light on this issue. Far from being mere abstract idealisations, the value positions expressed by participants in this study connect quite directly with decision-making and action, and it is in this sense that creative individual responses to political events represent meaningful agency, albeit of a limited kind. We do not seek to argue that individuals can individually overcome structural constraints, but we do seek to encourage further dialogue around the extent to which individual decisions and actions, propelled by commitments to 'visions of the future' may lead us to a fuller understanding of the nature of the relationship between the individual and the social (and, by extension, the political) which may form a more robust basis for meaningfully theorising career (Stetsenko, 2015).

\section{Brexit: a wake-up call for career guidance?}

If the findings from this study can be considered as potentially relevant to the experiences of students from other universities, these could be interesting times for career guidance practitioners working in higher education. If we accept that our students' engagement in their world is a critical one, where any potential future action related to career is directed by their values and commitments, this opens up the opportunity for practitioners to revisit their practice in order to develop potentially more challenging strategies as the basis for career conversations. There may be some justification for spending time exploring clients' personal values and how these relate to potential career choice. We may also wish to consider the importance of managing the emotional impact of career decision-making in a world that seems to constantly change and may often feel alienating. Of course, as Thomsen and others have suggested, it may be that practice needs to shift from its preoccupation with individual success towards a more empowering community model. As wider access to graduate opportunities remains variable at best, it may become important for practitioners to engage more explicitly with the politics of career; to explore with students not only how to navigate and survive the world of work that is, but how they would like their world of work to be. 
Although practitioners 'may feel unsure about adopting a political position and [be] concerned about the ethics of passing on their own beliefs to clients' (Hooley, 2015, p.14), a model of guidance that actively recognises the importance of political context in career decision-making may be the most appropriate in a world increasingly characterised by economic and political uncertainty.

To date, career guidance theory and practice has tended to promote an individualistic approach to career decision making. In higher education, the drive to achieve positive graduate outcomes may have resulted in an approach that is primarily concerned with 'recruitability' (Grey, 2018), and that favours those who are emotionally tough enough and can win in the competition for graduate jobs. Despite widening participation initiatives by universities, inequalities in the labour market remain largely unchallenged and careers guidance practice has generally shied away from engaging with socio-political context. A blended approach to careers guidance is needed if we wish to have these more challenging career conversations; an approach that retains a focus on the individual (e.g. who am I? what motivates me? what do I want to achieve in life?) but does not isolate the individual aspects of experience from the broader socio-political realities that shape, constrain and enable both the material realities of experience and the creative imagination (e.g. what sort of society do I want to live in? what do I want to change? how could I be a part of that change?).

Not every student will want to change the world. However, every student, in some meaningful sense, will contribute to change in their world, even as a result of their ongoing engagement in what may appear to be the mundane or everyday. Graduate clients, like other clients, will be seeking a life that fits with their values and aspirations; with their commitments to an imagined future.

'Brexit really woke me up!' were the words of one participant in this study. Perhaps Brexit could also be part of a wake-up call for career guidance practice. If we believe that the next graduate generation is to take up the challenge of helping to create a more socially just society, then practitioners may need to be prepared to play their part too, and that may mean foregrounding in practice the political in both its personal and social dimensions. 


\section{References}

Alexander, R. (2018). 'Geography, mobility and graduate career development' in Burke, C. \& Christie, F (Eds), Graduate Careers in Context: Research, Policy and Practice (pp.99-109). London: Routledge.

Amundson, N. (2003). Active engagement: enhancing the career counselling process ( $2^{\text {nd }}$ edition). Richmond, Canada: Ergon Communications.

BBC News. (2018, 8 February). Brexit: Official forecasts suggests economies throughout the UK will be hit. [News release]. Retrieved from http://www.bbc.co.uk/news/uk-politics-42977967

Grey, M. (2018, 16 January). Has employability become a toxic brand? [Blog post]. Retrieved from https://wonkhe.com/blogs/has-employability-become-a-toxic-brand/. Accessed 3 January 2019.

High Fliers Research Limited. (2017, 12 July). New research shows fewer graduates from the 'Class of 2017' want to work for the City's top investment banks because of Brexit job fears. [Press release]. Retrieved from https://www.highfliers.co.uk/download/2017/uk graduate careers survey/Release20 17.pdf

Hobson, C. (2018, October). Demand for graduates in the midst of Brexit uncertainty: trends to watch in 2019. Retrieved from https://luminate.prospects.ac.uk/demand-forgraduates-in-the-midst-of-brexit-uncertainty-trends-to-watch-in-2019. Manchester:

Graduate Prospects.

Hooley, T. (2015, 17 September). Emancipate yourselves from mental slavery: Selfactualisation, social justice and the politics of career guidance. Retrieved from http://derby.openrepository.com/derby/bitstream/10545/579895/1/Hooley++Emancipate+Yourselves+from+Mental+Slavery.pdf. Derby: International Centre for Guidance Studies, University of Derby.

Hooley, T. and Barham, L. (Eds). (2016). Career development and public policy: The Tony Watts reader. Stafford: Highflyers.

Marx, K. (1973). Grundrisse: Foundations of the critique of political economy (Rough Draft). Harmondsworth: Penguin Books (in association with New Left Review).

McCrory, M. and O'Donnell, V. (2016). Developing a participant-centred approach to qualitative research interviewing. Theory and Method in Higher Education Research, Volume 2, 157-175. doi: 10.1108/S2056-375220160000002008

Recruitment International (2017, February 16). Graduate talent pool to get shallower as a third of UK international students reconsider staying and working in the UK. Retrieved from https://www.recruitment-international.co.uk/blog/2017/02/graduate- 
talent-pool-to-get-shallower-as-a-third-of-uk-international-students-reconsiderstaying-and-working-in-uk.amp. Accessed 4 December 2018.

Roberts, K. (2009) Opportunity structures then and now, Journal of Education and Work, 22:5, 355-368. doi: 10.1080/13639080903453987

Stetsenko, A. (2015). Theory for and as social practice for realising the future: Implications from a transformative activist stance. In J. Martin, J. Sugarman, and J. L. Slaney (Eds), The Wiley handbook of theoretical and philosophical psychology: Methods, approaches and new directions for Social Sciences. Oxford: John Wiley.

Thomsen, R. (2017). Career guidance in communities: A model for reflexive practice. Retrieved from:

https://derby.openrepository.com/bitstream/handle/10545/621596/Career+guidance+ in+communities+final 02052017+. pdf? sequence=1. Derby: International Centre for Guidance Studies, University of Derby.

Universities UK. (2018, 11 May). Minding our future. Retrieved from https://www.universitiesuk.ac.uk/policy-andanalysis/reports/Documents/2018/minding-our-future-starting-conversation-studentmental-health.pdf London: Universities UK.

\section{For correspondence}

Dr. Marjorie McCrory

Senior Lecturer and Programme Leader MSc Career Guidance and Development Marjorie.McCrory@uws.ac.uk

Theresa Thomson Careers Consultant theresa2.thomson@uwe.ac.uk 